Public corporate governance of state-owned enterprises: evidence from the Spanish banking industry

\author{
Tamyko Ysa ${ }^{1}$, Mireia Giné ${ }^{2}$, Marc Esteve ${ }^{1}$, and Vicenta Sierra ${ }^{1}$ \\ ${ }^{1}$ University Ramon Llull-ESADE \\ ${ }^{2}$ University of Pennsylvania-WRDS
}

\title{
Tamyko Ysa
}

ESADE

Av. Pedralbes, 60

08034 Barcelona (Spain)

Tamyko.ysa@esade.edu

Tamyko Ysa, Ph.D., is an Assistant Professor of the Institute of Public Management and Governance, and the Department of Business Policy at ESADE.

\section{Mireia Giné}

University of Pennsylvania-WRDS

400 Steinberg Hall - Dietrich Hall

3620 Locust Walk

Philadelphia, PA 19147 (USA)

gine@wharton.upenn.edu

Mireia Giné, Ph.D. is Director of Research at Wharton Research Data Services (WRDS) at the University of Pennsylvania, and Lecturer at the Finance and Accounting Department at ESADE.

\author{
Marc Esteve \\ ESADE \\ Av. Pedralbes, 60 \\ 08034 Barcelona (Spain) \\ marc.esteve1@esade.edu
}


Marc Esteve is a PhD Candidate in Management Sciences at ESADE Business School and he is currently a visiting researcher at Cardiff University.

\section{Vicenta Sierra}

ESADE Sant Cugat

Av. de la Torre Blanca, 59

08172 Sant Cugat (Spain)

Vicenta.sierra@esade.edu

Vicenta Sierra, Ph.D., is an associate professor in the Quantitative Methods Department at ESADE in Barcelona. Her research focuses on robust statistics, statistical simulation and psychometrics. 


\title{
PUBLIC CORPORATE GOVERNANCE OF STATE-OWNED ENTERPRISES: EVIDENCE FROM THE SPANISH BANKING INDUSTRY
}

\begin{abstract}
We examine the role of public corporate governance in the restructuring of the Spanish financial sector. State-owned savings banks or Cajas provide evidence of the conflict of interest in multilevel governance. We find that choice of the integration mechanism (merger, IPS or acquisition) can be explained by two drivers: geographical and political proximity.
\end{abstract}

\section{INTRODUCTION}

With the current economic crisis, the Spanish banking system has been under stress, and savings banks or Cajas, in particular, which have a strong public status, have been going through a major reorganization. Cajas carry significant weight in the banking sector since they represent half of the market share for loans and deposits and, for the last decade, they have experienced strong growth. However, they have also accumulated a high percentage of loans to the Spanish real estate industry and, therefore, suffer tougher problems of solvency than the private banking sector. This lack of solvency has triggered a process of integration that highlights both the public nature of Cajas and the conflict of interest between the regional and national government levels. Thus, the objective of this paper is to examine the drivers behind each integration and, more specifically, to study how the tension between the different levels of government is shaping the reorganization.

Cajas share a public status common to other non-private savings sectors in many European countries such as Austria, France, Germany, Italy and Russia (ESBG, 2009). 
They share a similar origin (founded by local or regional governments, churches, welfare societies and trade unions) and common goals to promote savings and provide lending to businesses and individuals in the region. This array of goals, which encompasses social and economic development, is one of the main features of Cajas. In addition, Cajas have an ownership structure involving various stakeholders: depositors (savers), local and regional governments, founders and employees. Moreover, national and regional regulation has translated this stakeholder ownership structure into different representative structures in the governing bodies of individual Cajas. That is, the legislator has determined the power of the governments and decision-making authorities in these institutions: both the general assembly and the board of directors have substantial representation of local and regional Governments (up to a maximum of $50 \%$ of voting rights until July 2010, and from then onwards up to $40 \%$ ). Within this governance framework, the need to reorganize the sector and find new efficiencies across Cajas has required the public sector to play an important role at several different levels: this is public corporate governance.

In Section II we present an overview of the Spanish state-owned banks and its governance characteristics that sets them apart from private banks. Section III presents the multi-level governance structure of Cajas and in section IV and V we examine the drivers behind the reorganization of the Spanish banking system.

\section{CAJAS IN THE SPANISH BANKING INDUSTRY}

As in many European countries, the Spanish banking system has two very distinct type of institutions: private banks and public savings banks. The Spanish savings banks or Cajas constitute an important network that have been increasingly competing with private banking institutions since the liberalization of the Spanish banking system in 1977 (see 
Figure 1 and González et. al., 2011). Cajas are credit entities with a strong commitment to promoting savings; they focus on the development of domestic economies and small businesses by providing an extensive network of offices; and they retain an important role in financing regional economies. A trait of these savings institutions is that they are required to distribute part of their benefits in social and cultural projects. These so-called "social dividends" reflect the not-for-profit nature of Cajas, which may often conflict with value maximization goals (Illueca et al., 2009). As García-Cestona and Surroca (2008: 583) indicate: "Spanish savings banks pursue, by law, a wide set of goals. Furthermore, given the absence of shareholders, making a profit becomes only one among several measures of success."

Another important characteristic of these Cajas concerns their links with both local governments and autonomous communities -regional governments- (their regulation itself advocates this). Local and regional governments are part of the governance structure up to a $50 \%$ as founding entities and, at the same time, regional governments are the regulators of Cajas inside their territories. The result is that "Cajas are an unusual segment of the Spanish financial sector, characterized by heavy political involvement; as a result, moves towards changing the regulation of the segment are continuously being discussed." (Cuñat \& Garricano, 2009: 2). 
Figure 1. Comparison of Cajas and bank percentages in terms of the total Spanish banking system — in assets

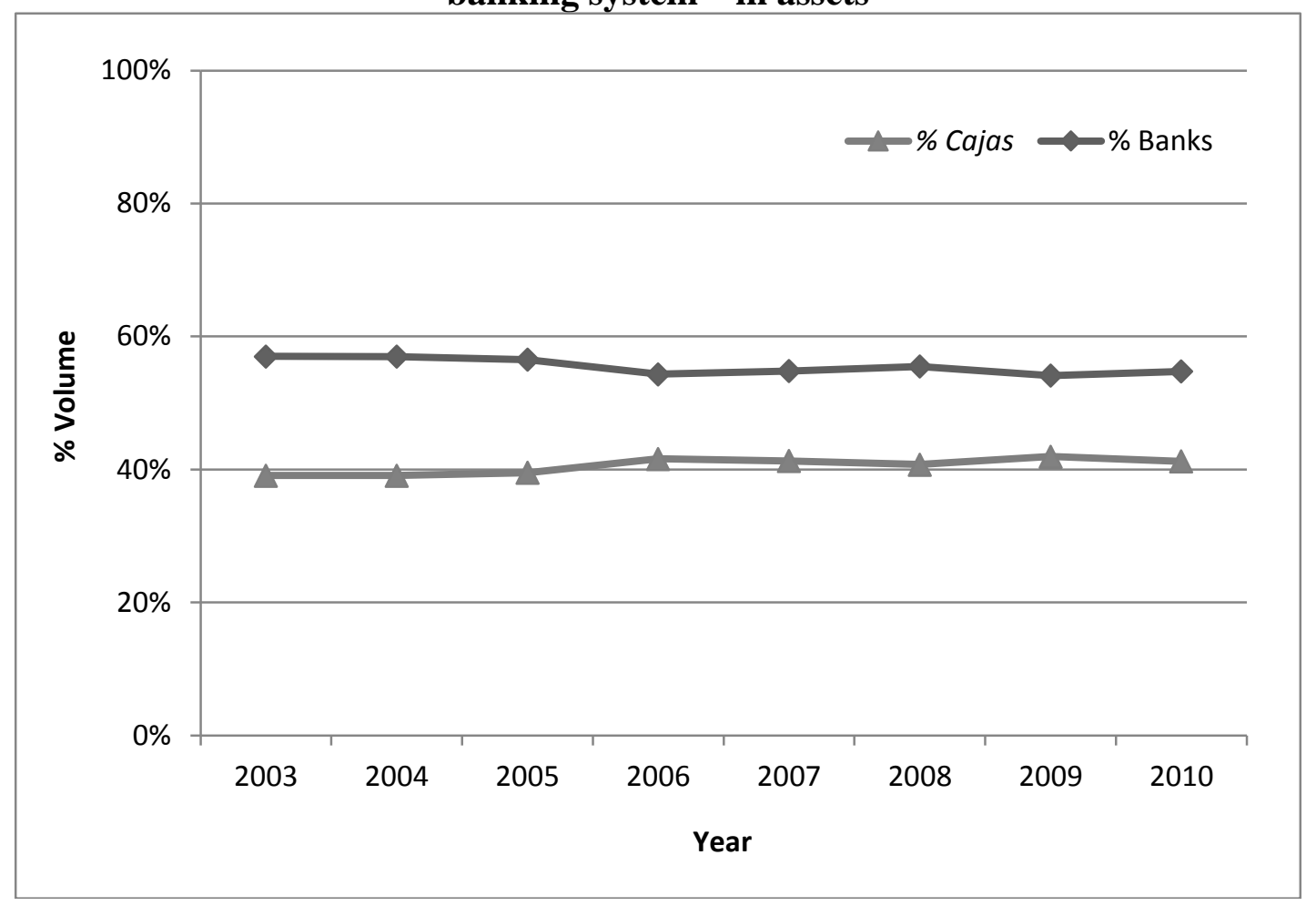

Source: Constructed using data from the Bulletin of the Bank of Spain (www.bde.es) ${ }^{1}$

Cajas are radically different from the private Spanish banking system; two striking institutional features set them apart. First, Cajas cannot raise capital by issuing shares. This limitation has forced Cajas to grow either by using debt to access capital or by merging with other institutions. In this respect, there is asymmetric competition with the private banking sector: while Cajas can acquire privately owned banks, their ownership structure means that banks cannot acquire Cajas. Moreover, Cajas are not quoted in the stock market. The fact that Cajas are completely isolated from the market of corporate control eliminates an important source of discipline for its managers. In contrast with other banks,

\footnotetext{
${ }^{1}$ http://www.bde.es/webbde/es/estadis/infoest/a04a.pdf [Accessed 17th March 2011].
} 
Cajas are not susceptible to takeover if they underperform. Second, instead of shareholders Cajas have a complex system of stakeholders that includes the founding entities, the regional government, municipal corporations and their employees, among others. Thus, they do not represent only the organization's owners, as shareholders do; they represent the organization's environment.

Given the lack of shares, the distribution of voting rights within the governing bodies is determined by law. Cajas have three main sources of regulation: the national government -which regulates the minimum common framework for Cajas in Spain-, the Bank of Spain (central bank), and the regional governments, which have the power to regulate the management of Cajas established in their regions. Thus, Cajas have three main governing bodies defined by national legislation: the general assembly, the board of directors and the control commission. In addition, regional regulations have established different stakeholder categories and their corresponding voting rights in the general assembly, the senior governing body. The distribution of representation follows (minimum-maximum \%): public sector organizations $50 \%$, depositors $25-50 \%$, founding bodies $5-35 \%$, employees $5-15 \%$, and other (business organizations, universities, etc.) maximum $10 \%$. The size of the general assembly varies between 60 and 160 members, depending on the institution.

Next, the board oversees management and defines the strategy of the organization. The board also represents the different stakeholders, but here its membership is smaller, between 13 and 20, and its composition is not strictly proportionate to the general assembly (Melle, 1999). The board designates the executive director and has the power to fire him or her. It is also possible for the president to be the executive director. Table 1 shows the representation structure of the boards of directors of two important Spanish Cajas. 
Table 1. Board representation

\begin{tabular}{|l|r|r|}
\hline & \multicolumn{1}{|c|}{ La Caixa } & \multicolumn{1}{c|}{ Caja Madrid } \\
\hline Representatives & Num. Board Members & Num. Board Members \\
\hline $\begin{array}{l}\text { Public administrations (local and } \\
\text { regional governments) }\end{array}$ & $4(19 \%)$ & $10(47 \%)$ \\
\hline Representatives of depositors & $8(38 \%)$ & $7(33 \%)$ \\
\hline Founder entities & $6(28 \%)$ & $0(0 \%)$ \\
\hline Employees & $3(14 \%)$ & $2(9 \%)$ \\
\hline Representative entities & - & $2(9 \%)$ \\
\hline Total & $21(100 \%)$ & $21(100 \%)$ \\
\hline
\end{tabular}

Source: Constructed using data from corporate information published on Cajas websites $2010^{3}$.

Finally, the control commission has between 5 and 15 members and its role is to monitor the board and report to the central bank. In a nutshell, this structure of representation and control induces potential conflicts of interest among the myriad stakeholders who make up the governing bodies. Seen through the lens of agency theory, these institutions exemplify a serious governance challenge. The existence of multiple stakeholders with actual governing 'voice' may generate problems in deciding valuemaximizing strategies for the Cajas. It may also generate weak internal corporate governance mechanisms, poor monitoring and lack of systems to discipline management.

\section{THE ROLE OF THE PUBLIC SECTOR: MULTILEVEL GOVERNANCE IN SPANISH CAJAS}

The OECD (2005) defines banks with public participation by national and/or regional governments as state-owned banks -such as Spanish savings banks or Cajas. This

\footnotetext{
${ }^{2}$ La Caixa and Caja Madrid ranked as No. 56 and No. 98, respectively, in The Banker 2003 Top 1000 World Bank ranking.

${ }^{3}$ La Caixa http://portal.lacaixa.es/infocorporativa/gobiernocorporativo_es.html [Accessed 17th March 2011).

Caja Madrid

http://www.cajamadrid.com/CajaMadrid/Home/cruce/0,0,84630\%24P1\%3D401,00.html [Accessed 17th March 2011].
} 
participation is represented in the board of directors of the bank, and its ownership percentage can vary from a minority to more than the 50\%, depending on the country (OECD, 2005; Ianotta et al., 2007). In the Spanish case, there is as well a regulatory channel that regional governments may use to exert power over Cajas given that, from 1985, the Spanish Constitutional Court recognized that the regulation of Cajas should be granted to regional governments (as part of the devolution process). Figure 2 depicts the different paths regional governments may use to influence the governance of Cajas: either via regulation or through direct participation in governing bodies. 
Figure 2. Cajas public corporate governance

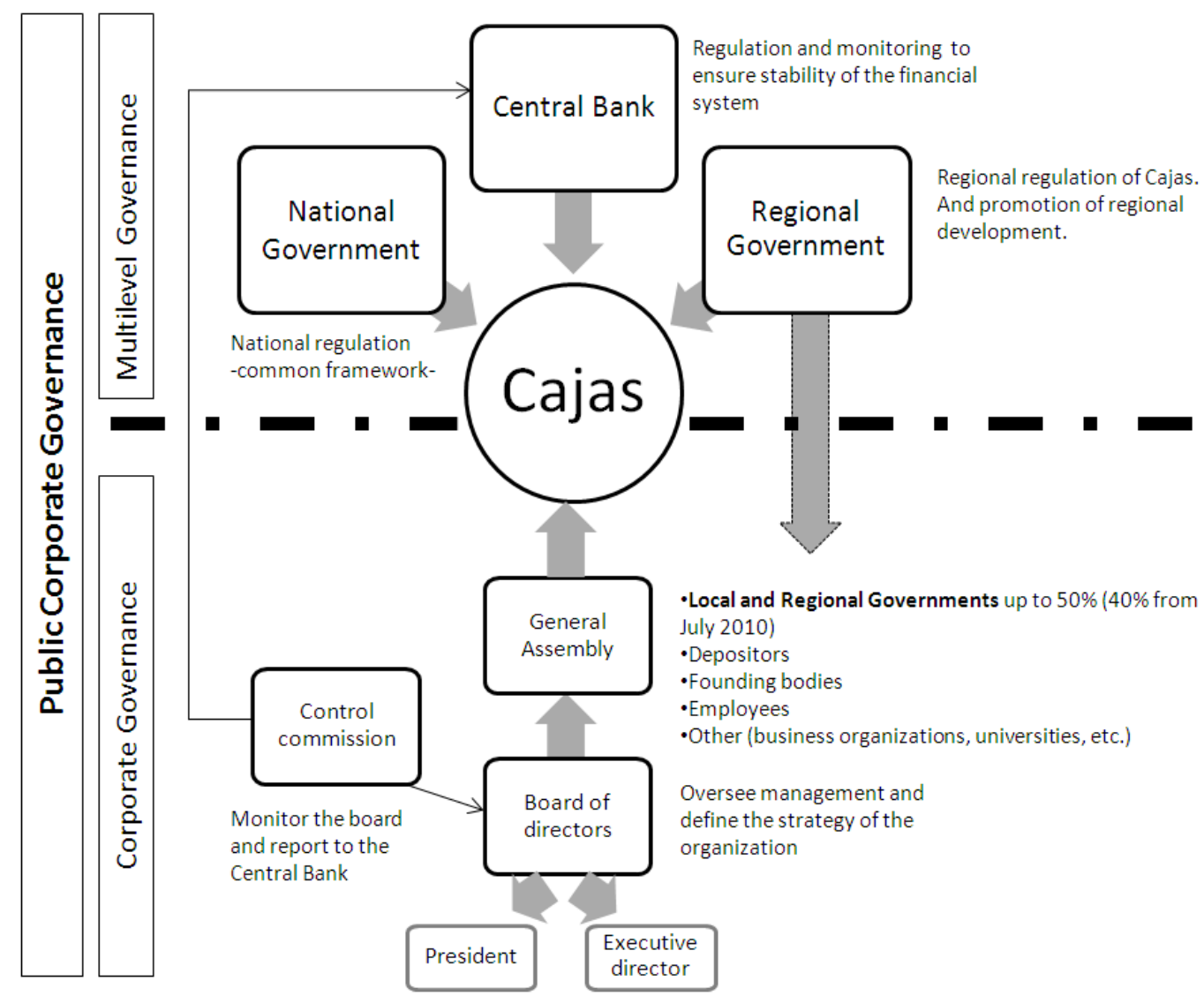

Given this regulatory framework, the risk of politicizing the governance of these entities has always been a source of conflict (Melle \& Maroto, 1999; Azofra \& Santamaría, 2002; La Porta et al., 2002; Sapienza, 2004; Fonseca, 2005). Each regional government has developed ad hoc regulatory solutions to preserve the control inside their territories - for example, the maximum age at which presidents can retire, or the veto power for approval of mergers. Until July 2010, under Spanish legislation, regional governments could veto unwanted integrations.

Moreover, regional governments may use the law to distribute the benefits to social and cultural projects in their region. Historically, Cajas have been perceived as an ally for 
local development policies. It is often the case that key regional development projects are carried out with the financial support of the regional Caja (Melle \& Maroto, 1999; Azofra \& Santamaria, 2002; Fonseca, 2005). The interplay between social-economic and political interests is a lever for these types of project. Indeed, the territorial and identity component of the Cajas has always been an important factor in their social integration and economic success.

Cajas have acted for the general interest benefit through complying with their social function: "Cajas benefits devoted to social goods and services in the regions has been a supporting feature of the Spanish welfare state" (General provisions of Cajas law, L11/2010). Currently, 88\% Cajas have collaboration agreements with the public sector regarding welfare services (CECA, 2010). This mission has been channelled through the "Social and Cultural Welfare Project" (SCWP), which in 2009 invested $€ 1.775$ Mn (almost the same amount that Spain received in Structural Funds from the European Union: $€ 1.845$ Mn) -see Figure 3 for an evolution-. 
Figure 3. Cajas funds initial provision to finance the "Social and Cultural Welfare Project"

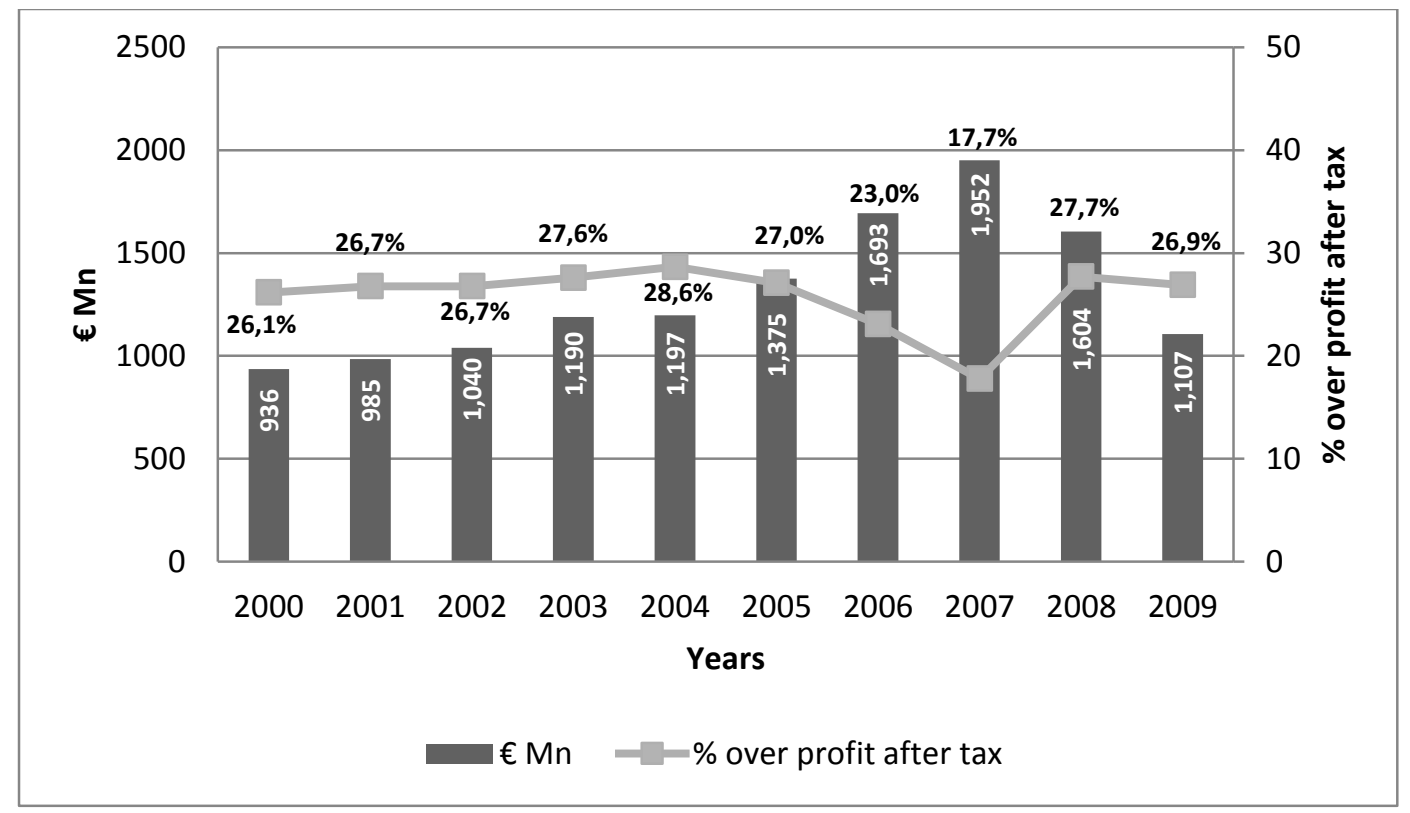

Source: CECA "Social and Cultural Welfare Project" reports 2000-2010. The Spanish Confederation of Savings Banks.

The allocation of these resources is focussed in four main areas (2009): social welfare and healthcare (41\%), culture and free time (33\%), education and research $(17 \%)$ and historic and natural heritage (9\%) (CECA, 2009). It is noticeable the importance of the foundations that manage the SCWP inside Cajas. Two of them, La Caixa Foundation and Caja Madrid Foundation are $3^{\text {rd }}$ and $6^{\text {th }}$ among the top 50 European foundations by expenditure (Philantrophy, 2009). And they have to invest, by law, this SCWP in the regions where Cajas are based.

In sum, Cajas, as state-owned banks, operate within a duality of objectives: on the one hand, it seeks profit maximization as any other commercial bank; but on the other hand, it provides financial support to economic and social activities in the region it operates (Apreda, 2006). 
In the next section, we present the outcomes of the restructuring process due to the financial crisis. In order to do so, a process of data collection has been developed including the following sources: national regulation, regional regulations, orders of the central bank, policy makers public declarations for three years (President of Spain, ministry of economy, president of the central bank, presidents of regions and its ministers, European commissioners) and stakeholders (presidents from Cajas, Association of Cajas, unions, and think tanks).

\section{THE RESTRUCTURING OF THE SPANISH BANKING INDUSTRY}

Cajas have had an important role in the Spanish financial system. García-Cestona and Surroca (2008) state that "the market share of savings banks in 2004 was slightly higher than that of commercial banks: $48 \%$ vs. $47 \%$ in the loan market and $52 \%$ vs. $42 \%$ in the deposit market." Since the 1990s, Cajas have experienced a dramatic expansion of branches as well as volume of assets. Moreover, they argue that the expansion out of the regions is associated with more aggressive growth in lending and reallocation within the loan portfolio. There has been a shift away from safer lending towards riskier commercial and mortgage lending. For instance, the share of real estate loans in the Cajas books in 2006 has ranged from $10 \%$ to $50 \%$. These percentages are extremely large considering that by the end of 2008, the volume of loans to real estate developers and builders reached almost $€ 500$ billion, equivalent to 50\% of Spain’s GDP (Cuñat \& Garicano, 2009). Indeed, this increase in debt in a sector with high default rates (around 5.05\%) has generated severe solvency problems and prompted the current transformation of the Spanish banking sector. 
In 2008 the central bank decided to recommend a reorganization of Cajas to ensure their financial survival. It demanded a reform focused on two areas. First, it advocated for a reorganization of those Cajas under the greatest economic stress, urging them to merge. Second, it attempted to reduce the power of the regional governments by requesting a reform of the Cajas law. The central bank's plan was based on three ideas: 1) Cajas need to rationalize their resources; 2) this should be achieved via mergers between entities; and 3) the adjustment should be completed by the summer of 2010 and, if needed, financial assistance would be provided by the central bank's Fund for Orderly Bank Restructuring (or FROB).

The FROB is a public entity concerning bank restructuring and reinforcing the equity of credit entities. Access to FROB funds (with an initial allocation of $€ 9,000 \mathrm{Mn}$ ) is conditional on Cajas reorganizing their extensive branch networks and resizing via integration. One of the reasons behind the haste to use FROB (approved in July 2009) is that the European authorities have set a limit before they force its closure ${ }^{4}$. The European Commission has established a calendar for fund duration since they consider that state aid damages competition and breaches the regulation of the interior market.

As of December 2010, 40 Cajas out of a total of 45 had been involved in the restructuration of the sector starting in 2008. Table 2 displays the 14 integration processes detailing the members of each case, the type of process, whether the integration is within or across regions and the level of funding support from FROB. Nowadays, the number of Cajas has been reduced to 19 via several mechanism: mergers, Institutional Protection Schemes (IPS), or acquisitions.

\footnotetext{
${ }^{4}$ On January 2010, the European Comission approved the Spanish recapitalization scheme for banks aimed at enhancing the strength and solvency of credit institutions (State Aid N-28/2010). This scheme has been in place till December 2010.
} 
Table 2. Map of integration processes of Spanish Cajas opened with the crisis

\begin{tabular}{|c|c|c|c|c|c|}
\hline Process & Savings banks involved & Type & $\begin{array}{l}\text { Within/ or } \\
\text { across } \\
\text { regions }\end{array}$ & Assets in $€ M n$ & $\begin{array}{c}\text { Requested aid } \\
\text { from FROB } \\
(€ M n)\end{array}$ \\
\hline 1 & $\begin{array}{l}\text { CATALUNYA CAIXA } \\
\text { Catalunya } \\
\text { Tarragona } \\
\text { Manresa }\end{array}$ & Merger & Within & 76.649 & 1.250 \\
\hline 2 & $\begin{array}{l}\text { UNNIM } \\
\text { Sabadell } \\
\text { Terrassa } \\
\text { Manlleu } \\
\end{array}$ & Merger & Within & 28.548 & 380 \\
\hline 3 & $\begin{array}{l}\text { La Caixa } \\
\text { Girona }\end{array}$ & Merger & Within & 271.338 & - \\
\hline 4 & $\begin{array}{l}\text { Cajastur } \\
\text { CCM }\end{array}$ & Acquisition & Across & [View process 5] & - \\
\hline 5 & $\begin{array}{l}\text { BANCO BASE } \\
\text { CAM } \\
\text { Cajastur-CCM } \\
\text { Caja Cantabria } \\
\text { Extremadura }\end{array}$ & IPS & Across & 125.562 & 1.493 \\
\hline 6 & $\begin{array}{l}\text { BANCO MARE NOSTRUM } \\
\text { Murcia } \\
\text { Penedes } \\
\text { Sa Nostra } \\
\text { Granada } \\
\end{array}$ & IPS & Across & 71.026 & 915 \\
\hline 7 & $\begin{array}{l}\text { Unicaja } \\
\text { Jaen }\end{array}$ & Merger & Within & 54.817 & - \\
\hline 8 & $\begin{array}{l}\text { BANCO CAJA 3 } \\
\text { CAI } \\
\text { Circulo } \\
\text { Badajoz }\end{array}$ & IPS & Across & 20.145 & - \\
\hline 9 & $\begin{array}{l}\text { BANCO FINANCIERO } \\
\text { Caja Madrid } \\
\text { Bancaja } \\
\text { Insular } \\
\text { Laietana } \\
\text { Avila } \\
\text { Segovia } \\
\text { Rioja }\end{array}$ & IPS & Across & 334.508 & 4.465 \\
\hline 10 & $\begin{array}{l}\text { NOVA CAIXA GALICIA } \\
\text { Galicia } \\
\text { Caixanova }\end{array}$ & Merger & Within & 75.549 & 1.162 \\
\hline 11 & $\begin{array}{l}\text { CAJA ESPAÑA-DUERO } \\
\text { Caja España } \\
\text { Caja Duero }\end{array}$ & Merger & Within & 46.017 & 525 \\
\hline 12 & $\begin{array}{l}\text { BANCA CIVICA } \\
\text { Cajasol } \\
\text { Guadalajara } \\
\text { Navarra } \\
\text { Burgos } \\
\text { Canarias }\end{array}$ & IPS & Across & 71.306 & 977 \\
\hline 13 & $\begin{array}{l}\text { Cajasur } \\
\text { BBK }\end{array}$ & Acquisition & Across & 47.000 & - \\
\hline
\end{tabular}




\begin{tabular}{|c|c|c|c|c|c|}
\hline 14 & $\begin{array}{l}\text { BBK } \\
\text { Kutxa } \\
\text { Vital }\end{array}$ & $\begin{array}{l}\text { Merger } \\
\text { (Failed, } \\
\text { leaving door } \\
\text { open for } \\
\text { future } \\
\text { process) }\end{array}$ & Within & 78.300 & - \\
\hline
\end{tabular}

Source: Constructed using data from FROB (2011) and economic media follow up.

Three integration mechanisms have been used: in $15 \%$ of the cases an acquisition took place, in $46 \%$ of the cases were mergers and $39 \%$ were IPS. One innovation in the integration process is the use of a new restructuring formula: Institutional Protection Schemes (or IPS), also called virtual or cold integration. Integration under IPS allows entities to operate separately within their own territories, maintaining their own legal personality, commercial brand, governance systems, and regional commitment, but functioning as a single group regarding risk policies and management: credit risk, market risk, liquidity risk, interest rate risk and operational risk. Instead of creating one new entity from the union of others, a new, higher organizational entity -an umbrella- is formed. This formula allows operational integration in the form of shared services, technology and additional commercial networks. In these cases, the central bank must approve the project, and this requires the presentation of a viability plan, including synergies and cost reductions. Although the central bank prefers mergers to IPS, it recognizes that this channel allows for some cost saving, though it does not eliminate duplication of management and governance systems. 


\section{DOES MULTI LEVEL GOVERNANCE CONFLICT MATTER? OUTCOME OF THE RESTRUCTURING OF THE SPANISH BANKING SYSTEM}

So far we have provided evidence for multilevel governance in Cajas and we have presented the mapping of the restructuring process. In this section we examine the variables driving each type of restructuring process and the role of multilevel governance in determining the final outcome.

The hot political and economic debate on the integration process has been between two arguments that refer to the duality of Cajas' mission: first, gaining efficiency to deal with the solvency problems and second, keeping their "Social and Cultural Welfare Project" (SCWP, or "Obra social” in Spanish). Table 3 presents the key motivations and sources of power by the different decision makers involved in the restructuring process. The national government main goals have been to push for efficiency gains and a less politicized financial sector. It has used regulation at the national level as a means to achieve it - for example, in July 2010 a new regulation was passed that limited the voting rights of the regional and local governments from $50 \%$ to $40 \%$, and required that a third of the board members of the resulting financial entities to be independent. In contrast, regional governments aim to maintain the economic involvement of Cajas in their regional areas and to maximize the investment in SCWP. Their sources of power are veto power, regulation and voting rights at the governing boards. 
Table 3. Decision makers' goals in integration process

\begin{tabular}{|c|c|c|}
\hline Decision maker & Goals & Sources of power \\
\hline National government & \multirow{2}{*}{$\begin{array}{l}\text { - Gaining efficiency to } \\
\text { access markets } \\
\text { - A non politicized } \\
\text { financial map }\end{array}$} & $\begin{array}{ll}\text { - } & \text { National regulation } \\
\text { - } & \text { Economic policy } \\
\text { - } & \text { Alignment with central } \\
& \text { bank }\end{array}$ \\
\hline Central bank & & $\begin{array}{ll}- & \text { Fund for Orderly Bank } \\
\text { Restructuring (FROB) } \\
\text { - } \\
\text { - } \\
\text { Orders }{ }^{5} \\
\text { nutonomy from the } \\
\text { (credible voice) }\end{array}$ \\
\hline Regional governments & $\begin{array}{l}\text { Maximization of the } \\
\text { Social and Cultural } \\
\text { Welfare Project (SCWP) } \\
\text { as co-builder of the } \\
\text { regions welfare state } \\
\text { Regional development: } \\
\text { Cajas as bond buyers, } \\
\text { credit givers and } \\
\text { investors }\end{array}$ & $\begin{array}{ll}\text { - } & \text { Founder members of } \\
& \text { Cajas } \\
\text { - } & \text { Corporate management } \\
\text { voting rights } \\
\text { - } \\
\text { Regional regulation - } \\
\text { devolution rights- } \\
\text { - Veto power on alliances }\end{array}$ \\
\hline
\end{tabular}

How have the different motivations stemming from multilevel governance affected the outcomes of the restructuring process? We investigate whether the alliances are following a geographic proximity (within region alliances, or neighbouring regions), political proximity (the same party in the regional government) or business efficiency and diversification (out-of-region integrations). The response to the call for the integration of Cajas has been to use criteria of geographical (same region) and political proximity, giving way to a third alternative when the former is not applicable (see Table 4).

\footnotetext{
${ }^{5}$ I.e. the central bank can impose restrictions on Cajas' SCWP (since Feb 2011) to strength their reserves.
} 


\section{Table 4. Drivers of restructuring processes}

\begin{tabular}{|c|c|c|c|}
\hline \multirow{2}{*}{ Proximity } & \multicolumn{2}{c|}{ Political } \\
\cline { 3 - 4 } & $\begin{array}{c}\text { Same political party } \\
\text { in gov't }\end{array}$ & $\begin{array}{c}\text { Different political } \\
\text { parties in gov't }\end{array}$ \\
\hline \multirow{3}{*}{ Geographical } & $\begin{array}{c}\text { Same } \\
\text { region }\end{array}$ & MERGERS & - \\
\cline { 2 - 4 } & $\begin{array}{c}\text { Out of } \\
\text { region }\end{array}$ & ACQUISITIONS & $\begin{array}{c}\text { INSTITUTIONAL } \\
\text { PROTECTION } \\
\text { SCHEMES }\end{array}$ \\
\hline
\end{tabular}

From the 13 integration processes outlined in Table 2 (the failed process is out of the analysis), we find all the cases of mergers took place within the same region. None of the 13 integration processes took place among neighbouring regions. That is, either we find mergers within the same region or IPS across regions. In the case of the two acquisition processes we find that they are driven by political proximity since both regions are governed by the same party (PSOE). Moreover, we find that IPS are the preferred option when Cajas need to integrate beyond regional borders and there is no political proximity among the participating regions.

Initially, in late 2008, most management teams of Spanish Cajas were negotiating merger plans that included entities in other regions. However, it is surprising to see that, as of December 2010, $46 \%$ percent of the integrations occur between Cajas within the same region. This result fits the main goal of regional governments, that is, to keep Cajas as partners in their economic policies for regional development ${ }^{6}$. For mergers across different regional areas, Institutional Protections Schemes (IPS) have been the solution: a virtual integration across different territories with different clients profiles and risk diversification.

\footnotetext{
${ }^{6}$ The regional presidents themselves were making those claims. And Cajas presidents were informing about these political interferences in the process.
} 
Through the IPS a certain level of influence is kept in Cajas' original regional territories, while following the central bank goal for efficiency.

Further analysis on IPS offers information regarding which kind of saving banks are clustering together. Historically, Cajas in Spain have been considered with a more or less public status depending on the percentatge of public sector participation in their governing bodies. Using a well established classification by Fonseca (2005) we map the level of public sector representation for each integration process in Figure 4.

Figure 4. Public cajas and IPS

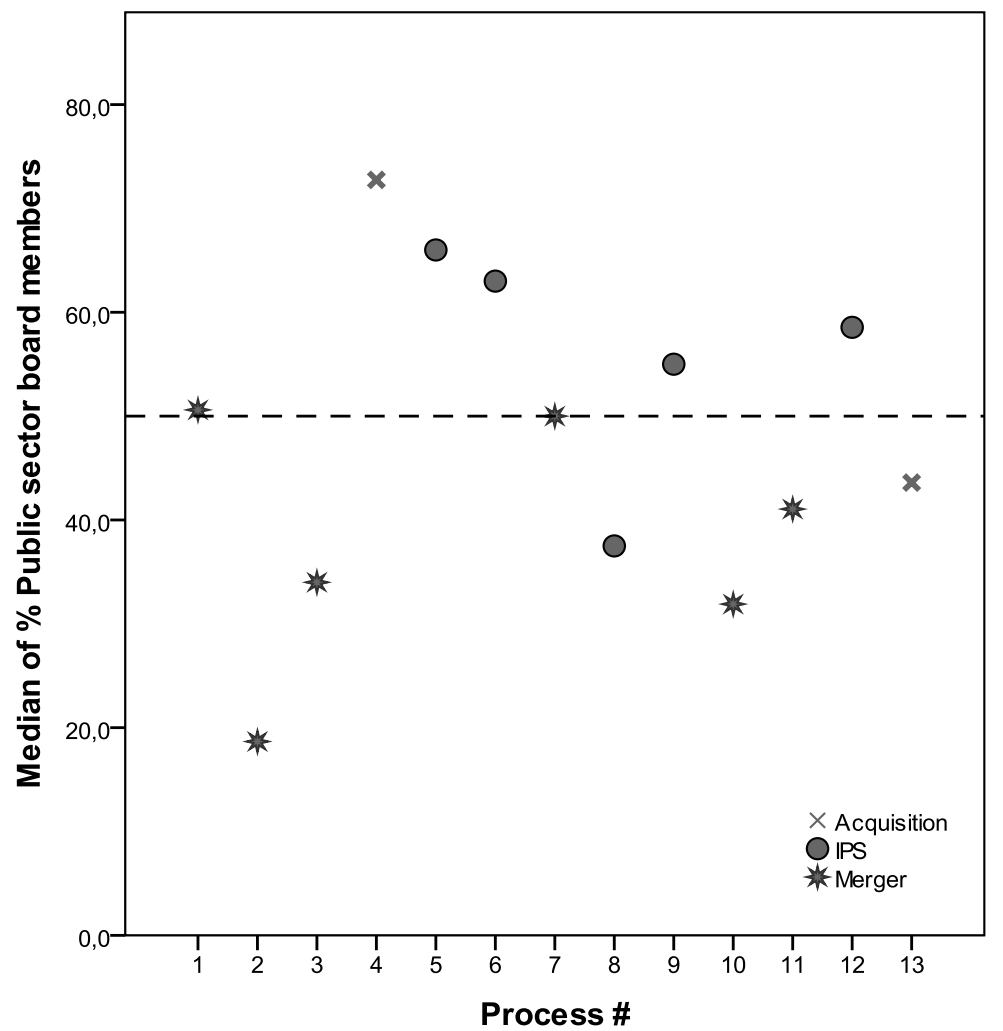

Source: Constructed based on the classification of public Cajas by Fonseca (2005) and FROB (2011).

The vertical axis in Figure 4 represents the median of the percentage of public sector representation at the board of each participating Caja. We use this measure as a proxy for 
the political influence regarding the decision making in the Cajas. In the horizontal axis, each number corresponds to a restructuring process, in same order as Table 2. We find that mergers are associated with Cajas with less public representation in their boards; while most IPS are bringing together Cajas that traditionally have had a more public status.

This result fits with the framework provided in Figure 2 on the two main channels that regional government may use to exert influence. In sum, since all mergers cases have remained in the same region, regional governments will continue to use regulation as the main vehicle to exert influence. In contrast, for IPS cases across regions, it is necessary for the different regional governments to have direct representation in the governing boards.

\section{CONCLUSIONS: LESSONS FOR POLICY MAKERS}

Since July 2008, the Spanish banking sector has gone through a major reorganization of its State-owned Savings banks or Cajas — which represent half of the financial sector. These entities have a public status since both local and regional governments have historically been important stakeholders and have voting rights in their governing bodies. Given the public nature of Cajas, the central bank of Spain and the national government have additional roles as regulators and monitors of these institutions. The much needed reorganization of the sector has evidenced the contrasting goals and conflict of interest among the different governments. The objective of the paper has been to examine how this multilevel governance frame plays a role in determining the outcome of the current financial reorganization.

The first contribution of the paper is to provide a framework for Public Corporate Governance. Figure 2 highlights the two main components: first, the traditional corporate governance mechanisms (via governing bodies and voting rights) and, second, the 
multilevel governance across public sector institutions that exert influence via regulation and monitoring.

With this framework in hand, we describe the different goals and sources of power among the three main players in the reorganization process: the regional governments, the national government and the central bank. We provide evidence for the conflict in multilevel governance which revolve around two main goals: either aiming for efficiency gains and to reconvert Cajas into non-politicized financial entities, or aiming for the maximization of Social and Cultural Welfare Projects within the regions.

Next, we provide a general picture of the reorganization of the Spanish banking system: from the initial 45 Cajas, there have been 14 integration processes resulting into 19 new financial entities. Three integration mechanisms have been used: in $15 \%$ of the cases an acquisition took place, in $46 \%$ of the cases were mergers and $39 \%$ were IPS.

It is striking to find that all mergers are within region and all IPS across regions; the acquisitions cases respond to political proximity. Regional governments have been using their sources of power within region (regulatory power and, most importantly, veto power) to defend that mergers occur among Cajas sitting inside their areas of regional influence. When the mergers within regions have not been deemed possible, the option of the IPS or vitual merger has become the alternative. In the IPS cases, the channel to continue to exert influence in the new financial entity is via boardroom representation -since the regulation channel does not apply anymore. We find that IPS across regions take place among Cajas with high level of public representation in boards prior to the integration. This may induce similar levels of public representation in the new governing bodies of the resulting Cajas.

In sum, regional governments are using different strategies to influence the governance of the resulting Cajas: either via regulation in the cases of mergers within- 
region or through direct participation in governing bodies in the cases of IPS. The case of the reorganization of the Spanish financial sector is an example of Public Corporate Governance at work - where it is necessary to include the multilevel governance of public sector institutions to the standard corporate governance mechanisms.

Finally, the case of the restructuring of the Spanish banking system may have relevant policy implications for policy makers in other countries with state-owned banks government ownership of banks is a phenomenon that affects at least 80 countries around the world (La Porta et al., 2002). In such countries, the multilevel governance issues that

have arise in the Spanish case should give guidance regarding the divergence of interests among the different levels of public administration players. For instance, in our case, the Spanish government tried to spur the integration process via national regulation and it did not progress successfully given the veto power of the regional governments. Hence, policy makers should foresee the tension between goals and implementation mechanisms - i.e. the IPS formula, together with the FROB funding and the oversight of the central bank have managed to reach the desired integration outcome while encompassing the interests of all the involved parties.

\section{ACKNOWLEDGEMENTS}

This paper reports work undertaken by the authors as part of MICINN Research Award CSO2009/11351, and AGAUR Research Award SGR1483. Earlier versions of this paper were presented at the IRSPM Conference in Bern 2010, and the US/EU Dialogue Series: Finding Common Ground on Issues of Business \& Public Policy, Georgetown University, 
March 2011. The authors would like to thank the editor and referees for their helpful comments.

\section{REFERENCES}

Apreda, R. (2006), Dual Governance in State-Owned Banks. CEMA Working Papers: Serie Documentos de Trabajo 319. Universidad del CEMA.

Azofra, V.; Santamaria, M. (2002), La influencia del gobierno corporativo sobre la eficiencia de las cajas de ahorros españolas. Workshop en Finanzas, VI Foro de Finanzas de Segovia. http://ubr.universia.net/pdfs/UBR0022004048.pdf [Accessed January 2011].

Bank of Spain. (2010), www.bde.es [Accessed March 18th 2011].

CECA. (2002-2010), Savings Banks' Corporate Social Responsibility Report: Financial activity and corporate governance. The Spanish Confederation of Savings Banks. ww.cajasdeahorros.es/web_RSC_2009_eng/index.html [Accessed March 2011].

Cuñat, V.; Garricano, L. (2009), Did Good Cajas Extend Bad Loans? The Role of Governance and Human Capital in Cajas Portfolio Decisions. http://www.crisis09.es/monografia2009/pdf/11-cajas.pdf [Accessed November 2009].

ESBG. (2009), Retail banking in Europe: The way forward. European Saving Banks Group (ESBG)http://www.esbg.eu/uploadedFiles/Publications_and_Research_(ESBG_onl y)/Research/DOC_ESBG_REPORT.pdf. [Accessed 17 March 2011].

Fonseca, A. (2005), El gobierno de las cajas de ahorros: influencia sobre la eficiencia y el riesgo. Universia Business Review 8: 24-37.

FROB. (2011), www.frob.es [Accessed March 18th 2011]. 
García-Cestona, M.; Surroca, J. (2008), Multiple Goals and Ownership Structure: Effects on the Performance of Spanish Savings Banks. European Journal of Operational Research 187 (2): 582-599.

González, F.; Méndez, R.; Pineda, R. (2011), Auge, caída y transformación de las cajas de ahorro españolas: Lecciones para América Latina. Naciones Unidas CEPAL and AECID. Chile, Sección de estudios del desarrollo, núm. 237.

Ianotta, G.; Nocera, G.; Sironi, A. (2007), Ownership Structure, Risk and Performance in the European Banking Industry. Journal of Banking and Finance, 31, pp. 21272149.

Illueca, M.; Norden, L.; Udell. F. G. (2009), Liberalization, Corporate Governance, and Savings Banks, Money and Finance Research group (Mo.Fi.R.) - Univ. Politecnica Marche - Dept. Economics. http://ideas.repec.org/p/anc/wmofir/17.html [Accessed November 17, 2009].

La Porta, R.; Lopez-de-Silanes; Shleifer, A. (2002), Government Ownership of Banks. Journal of Finance 57: 265-301.

Melle, M. (1999), El Gobierno de la Cajas de Ahorro Españolas. Cuadernos Empresariales 9: 265-279.

Melle, M.; Maroto J.M. (1999), Una aplicación del gobierno de empresas: incidencia de las Administraciones Públicas en las decisiones asignativas de las cajas de ahorros españolas. Revista Europea de Economía de Empresa 8: 9-39.

OECD. (2005), Corporate Governance of State-Owned Enterprises. Paris: OECD.

Philanthropy in (2009), Europe. Crisis What Crisis. www.philanthropyineurope.com/articles/crisis_what_crisis.htm [Accessed March 2011]. 
Sapienza, P. (2004), The effects of government ownership on bank lending. Journal of Financial Economics 72: 357-384.

Stanton, T. H. (2009), Government-Sponsored Enterprises: Reality Catches Up to Public Administration Theory. Public Administration Review, 69(4), 632-639.

the Banker. (2003), Top 1000 World Banks. The Banker, 153(929), July. 